\title{
Shale Gas U-Turns in Bulgaria and Romania: The Turbulent Politics of Energy and Protest
}

\author{
Simon Devey / Viktor Goussev / Bianca Schwarzenburg / Marco Althaus \\ Technical University of Applied Sciences, Wildau, Germany
}

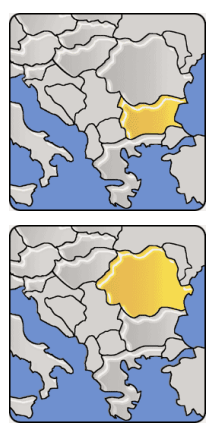

\begin{abstract}
After France, Bulgaria became the second EU country to enact an open-ended ban on hydraulic fracturing in early 2012. This government action was a radical departure from an initially friendly, even enthusiastic stance on unconventional gas development. It resulted in months of unprecedented, broad political protest from environmental groups and local communities. The conflict was interpreted as one involving old questions about Bulgaria's orientation toward Russia or the West. In neighbouring Romania, Bulgaria's U-turn on shale gas ener-
\end{abstract} gized a protest movement which had been relatively weak. In a turbulent election-year context, political leaders scrambled to deal with highly symbolic issues. A new government introduced a moratorium but ended it less than a year later. Another U-turn in public policy happened. Romania parted from Bulgaria's example and set out to move forward on shale gas, aiding foreign investors. Massive protests against the policy and the investors surged, encircling the drilling operations. In both countries, public mistrust in institutions, environmental regulations and due process of law is a significant factor of political risk for energy companies.

Keywords: Bulgaria, Chevron, civil society, communication, energy, energy policy, environment, fracking, hydraulic fracturing, moratorium, Nabucco, natural gas, pipelines, political risk, protest, Gazprom, Romania, Russia, shale gas, South Stream, unconventional gas, USA

Authors: Simon Devey and Victor Goussev are M.A. candidates, Bianca Schwarzenburg is a student in the B.A. in European Management at Technical University of Applied Sciences, Wildau, Germany, where Marco Althaus is professor of social sciences.

\section{Introduction}

Although they are very distinct countries with divergent energy supply situations, Bulgaria and Romania share many economic

\footnotetext{
${ }^{1}$ The Nabucco pipeline was planned to be constructed from the Turkish Bulgarian border via Romania and Hungary to Austria. It would supply natural gas from the Caspian Sea, i.e. Azerbaijan's Shah-Deniz field. The
}

and political features as well as energy policy challenges. In terms of per capita GDP, Bulgaria is the poorest, Romania the secondpoorest nation of the EU, which both joined in 2007 (Eurostat, 2013). Both postcommunist countries are hungry for economic development. Both had to seek EU and International Monetary Fund aid during the financial crisis years, and imposed austerity measures which triggered citizen unrest and anti-government protests. Both nations have very turbulent politics. Both countries are still deeply troubled by corruption and deficiencies in the rule of law and justice system. The European Commission still closely monitors and criticizes the slow pace of reform (Economist, 2014).

Their energy geography must be put in an EU context. Both nations have been deeply involved in the Southeast European corridor gas pipeline politics (e.g. Nabucco and South Stream). Both hoped to become key pillars of an Asian-European gas bridge, adding their own interconnector networks to diversify gas infrastructure. They could theoretically play a major role for Europe's energy supply security. The failure of the Nabucco pipeline project ${ }^{1}$ in 2013 was a disaster for both, but especially for Romania; Bulgaria still has a role in Gazprom's South Stream. Both countries have also set their sights on offshore gas drilling in the Black Sea. Finally, both countries have substantial unconventional gas reserves. This could mean not only a most-wanted economic boost but also more independence from Russian gas imports.

Since discovery, both countries went through a highly controversial debate on shale gas. Emergent issues around the hydraulic fracturing (fracking) technology energized environmental activism in both countries. Linked with anti-government civil unrest and protests, the anti-fracking movement grew surprisingly fast, putting immense political pressure on the governments.

Both governments first invited investors to apply for concessions and welcomed the new opportunities. But then both governments made a U-turn, giving in to enormous pressure from the street - both in the context of polarizing elections. Bulgaria's government reacted by outlawing the use of hydraulic fracturing and revoking drilling licences in early 2012. Romania also introduced a moratorium in 2012. This one, however, did not stand: Bucharest gave it up quickly, clearing the way for shale gas development.

Moreover, the two countries' controversies over shale overlap. It was Bulgaria's protest-induced total ban in early 2012 which put

highly political project was burdened with many difficulties. By June 2013 , the project was finally dead as the Shah-Deniz consortium opted for an alternative pipeline route, the Trans Adriatic Pipeline (TAP). 
Romania's anti-shale protests in motion. Protest organisers in the North and South cooperated, eased by the fact that U.S. firm Chevron was the major investor and preferred protest target in both countries. With Bucharest ending the moratorium, a new focus lay on the shale gas reserves located on the Romanian-Bulgarian border: Southern communities began to fear that despite their own country's ban, fracking activities on the Romanian side might contaminate and poison water and ground on their own side of the border. Bulgarians began to stage rallies in support of Romanian protests, and activists from both countries merged their campaigns in border towns (Novinite.com, 2013a, 2013b). They brought about the motto "Two Countries, Same Water - Two Nations, One Fight". Solidarity demonstrations also happened in front of the Romanian embassy in Sofia (Gaydazhieva, 2013).

As will be shown in this article, the developments of shale gas controversies in both countries have much in common. However, Bulgaria and Romania do differ in key contexts and the current government policies. In both countries, uncertainty, turbulence and surprises from political sources - in other words, political risk - is an eminent factor for any investor, but particularly in the context of a new and globally controversial technology. On top of this, opposition flared against foreign companies, seen as intruders.

Political risk may be defined as "any political change that alters the expected outcome and value of a given economic action by changing the probability of achieving business objectives" (PwC \& Eurasia Group, 2006). Though Bulgaria and Romania are part of the EU and therefore of a politically low-risk bloc compared to other parts of the world, the two countries score higher on any political risk mapper's assessment. The business environment is not as consistent and predictable as one might assume, and whoever trusts in the reliability of governmental and judicial decisions may learn instructive lessons from the shale gas cases presented here. Political events have been very fast-moving, and companies had to grapple with bouncing political logic and government reactions to threats and opportunities brought about by street-level action.

With a new and controversial technology, systematic communication efforts by governments and companies to gain social acceptance should have been a key component of contingency planning. The absence of such efforts greatly increased political risk.

\section{Bulgaria: The Road to the Ban}

While neighbouring Romania is relatively rich and diverse in its energy supply, Bulgaria is not. It is relatively poor in natural energy resources. It has limited lignite (brown coal) mining but has to import most all oil and gas, most from Russia. Next to burning coal, Bulgaria relies heavily on nuclear power. Atomic energy enjoys popular support and enables the country to export electricity.

As energy exporter, transit hub, distribution and logistics base, Bulgaria plays a significant role for South East Europe. This is due to its geography. Bulgaria has also been intensively developing its renewable sector. Its wind power sector grows fast. Overall, the energy sector, including major assets held by the state's Bulgarian Energy Holding, is well developed. Yet the country has suffered disillusionments about making the country an energy hub because power plants, pipeline, and other projects ran into economic, technical or political troubles. "Bulgaria has become notorious for the failure of many big energy projects" (Stoyanov, 2013).

Bulgaria's conventional oil and gas production used to be significant before the 1990s but has declined significantly since then. Today, the country imports almost all of its consumed oil and natural gas. From the 1970s through 2008, Bulgaria used to have a preferred relationship with Russian supplier Gazprom, with relatively low gas prices. The situation changed as Gazprom contract conditions changed and gas prices rose sharply, leading to angry citizen protests from 2008 onwards. The tendency is, however, that the country becomes more and more dependent on Russian imports. Local natural gas resources can satisfy only four percent of total consumption. Initially, Russian gas delivered through a pipeline built in the 1970s was used only by industry, but in the 1990s district heating began using gas. Directly, few households use natural gas; the share recently was around two percent, much lower than the European average (Georgiev, 2010).

After a local gas supply crisis in Sofia and major other cities in 2008, Bulgaria also suffered heavily from the Russian-Ukrainian payment dispute in 2008/09. Bulgaria's gas Russian supply comes from a single pipeline through Ukraine. For the first time in over 35 years, service stopped completely. The country was cut off and left in the cold (Stefanov \& Tsanov, 2012, p. 83). Industry and district heating companies suffered. Together with the economic crisis, the conflict led to a 20 percent drop in gas consumption in 2009, according to BulgarGaz (Georgiev, 2010).

After this experience, Bulgaria started to debate diversification and more independence from the Russian gas supply. A new energy strategy was forming. Increasing domestic production came into view as an option. This coincided with the growing international interest in unconventional gas reserves in Europe, especially Eastern and Central Europe. The U.S. Energy Information Administration (2013) estimates Bulgaria may have 481 billion cubic metres of recoverable shale gas reserves.

BulgarGaz, the domestic state-owned gas company, was not keen on exploring opportunities and probably lacked expertise and resources to do so. But by 2009/10, several foreign companies, mainly from the U.S. and Canada, expressed their interest in and applied for exploration licences to search for shale gas in Bulgaria's North. In response to the foreign investors' prodding, the centre-right government, led by the GERB party (Citizens for European Development of Bulgaria), opened the licensing process.

The energy ministry quickly prepared a series of tenders to auction off shale gas exploration concessions. Among the firms gaining permits in 2010/11 were Chevron (USA), Transatlantic Petroleum/Direct Petroleum Exploration (USA), Park Place Energy (Canada) (NGE, 2010). BNK Petroleum (USA) and Integrity Towers (USA) also expressed strong interest. In May 2011, in a rather spectacular and well-publicized move, Chevron outbid BNK Petroleum, offering the government "a whopping offer" of $€ 30$ million for a five-year concession - the state had actually only asked for a minimum price of $€ 200,000$ (Novinite.com, 2011b).

Energy minister Traicho Traikov gleed over the deal, and announced that Bulgaria's estimated shale gas deposits - now the talks was one trillion cubic metres - should be able to guarantee domestic consumption of natural gas for the next several hundred years (Novinite.com, 2011b). Traikov stressed that the "use of one's own resources has a potential that not a single country can allow to neglect. Because it gives security, independence and lower consumer prices." He stated, "if we get to industrial production, we will be getting tens of millions in concession fees a year" (NGE, 2011a). The government's rhetoric was excessively positive. That would prove to be a mistake with the distrustful public.

\section{Protests, elections, and "hysteria"}

Not everybody shared the government's enthusiasm. One problem lay in the fact that, since Bulgaria does not have a large oil and gas producing sector and the projects were all new, no specific legislation for unconventional gas was in place; only general laws for mining, environmental, soil and water protection provide rules for licensing and extraction (Kassabov, 2010a). The government did not deal much with the specific risk issues connected to hydraulic fracturing. Public concerns about environmental and health damage arose and intensified quickly when environmental groups 
began to campaign. A protest movement emerged quite fast, surprising in a country with a rather weakly organized civil society.

By July 2011, energy minister Traicho Traikov reacted by emphasizing that environmental concerns would be addressed by strict monitoring. But, he insisted, shale gas drilling would not be riskier than other mining (NGE, 2011a). Rising criticism began to make the government nervous. Political pressure grew and multiplied in the run-up to the October 2011 presidential election season. Opposition parties and candidates used the shale gas issue to position themselves against the government. Their message was: the government was out of sync with the people. In particular, the Bulgarian Socialist Party (BSP) moved the gas issue to the highly symbolic centre of its campaign. Socialist presidential candidate Ivaylo Kalfin demonstratively called for a national referendum to stop shale gas exploration (3e, 2011a). Energy minister Traikov said "a hysteria is being whipped up" (3e, 2011b).

In this overheated, polarized atmosphere, complex energy and environmental policy questions were reduced to partisan ammunition. Prime Minister and GERB party leader Boyko Borisov fueled hostility when he quipped at a local event that he would sign off shale gas permissions unless protestors stopped "nagging him:"

Nothing will happen if you stop irritating me. About those holding the signs, I wish to tell that they are enticed by a particular political party. If this keeps going on, we will sign the contract just out of sheer stubbornness. (NGE, 2011b).

This did not show prudence nor precautionary responsibility. It mirrored the government's incapacity to engage in any sustained information or persuasion effort to solidify shale support in public opinion. This stood in stark contrast to the opposition campaign, which provided a large quantity of negative communication on shale gas, exploiting the public's lack of balanced information. Anti-fracking material from foreign sources were spread, including the controversial U.S. film "Gasland." Film versions with Bulgarian subtitles were available on video sharing websites since mid-2011 (Wood, 2013, p. 2). Daborowski (2012), of the Polish OSW Centre for Eastern Studies, noted that anti-shale demonstrations were not large-scale events but they "were perfectly organised, coordinated and publicised in the media." The high watermark came in mid-January 2012, when thousands of protesters marched in eleven cities to demand a moratorium on exploration and statutory ban of the fracking method. Days later, the Borisov government and his GERB party totally shifted course, claiming that they could not act against the will of the people.

The cabinet decided to enact an indefinite ban on hydraulic fracturing. Licences were amended so only conventional methods could be used. The ban went into effect immediately and indefinitely. Companies that already had received permits were given three months to prove no fracking was involved. Offenders were threatened with a 100 million lev ( $€ 50$ million) fine. Further exploration tenders were cancelled. U.S. investor Chevron found its expensive exploration permit for the Novi Pazar area revoked for allegedly insufficient evidence of environmental safety. (Konstantinova \& Carroll, 2012; Novinite.com, 2012a; Sofia Echo, 2012).

The parliament voted overwhelmingly for the ban: Most of the opposition went along with the government's and GERB party's proposal. The parliament had not had any major debate on shale gas, and it did not commission any scientific study before the vote (Assenova, 2012a). Only months later did the parliament, on request of the government, install a special committee to study shale gas issues in general and review certain technical issues that they had voted upon earlier (Ivanova, 2013). Notably, the parliament did not pass a statutory law but a simple resolution ("reshenie"), which theoretically could be removed quickly (Daborowski \& Groszkowski, 2012, p. 9). For energy minister and shale enthusiast Traikov, developments were a personal defeat. He admitted that the government had been unable to prevent extreme polarization, and that he personally had underestimated "the level of hysteria that occurred." He regretted that further research on Bulgaria's deposits was now impracticable: "I definitely would like to know how much natural gas resources we have, but in these conditions we cannot do it" (Novinite.com, 2012c).

All decisions can be seen to be of purely political motives. The government's U-turn sent out a message to foreign investors that companies cannot take any government authorisation, once given, for granted: business faces high political risks in Bulgaria. In effect, Bulgaria has an unlimited political moratorium on shale gas exploration with a concrete ban of hydraulic fracturing, which is why we will subsequently call it a ban rather than a moratorium.

\section{Why environmental opposition flared}

In a remarkably short period of time, Bulgaria's society had become very sensitive about the hydraulic fracturing method. The reasons were those well known in international debate: assumed risks of ground and drinking water pollution by chemicals, seismicity ("earthquakes"), unwanted industrialisation and disruption of country life, damage or destruction of roads and farmlands. From the environmentalists' point of view, the consequences of contamination could be irreversibly damaging and catastrophic.

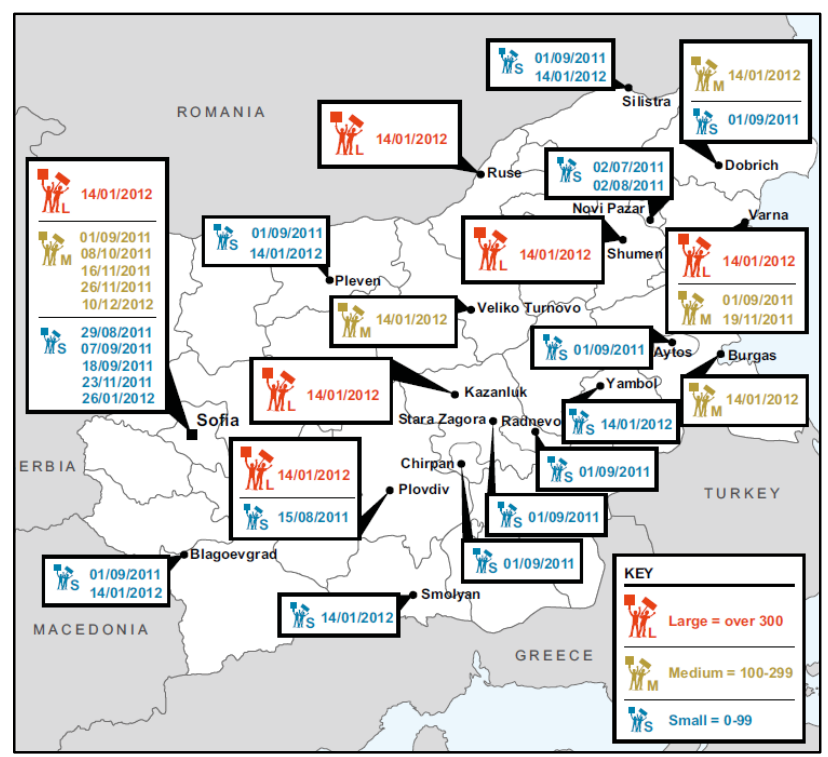

Figure 1. Bulgarian anti-fracking protests ahead of the moratorium, July 2011 to January 2012, as accounted for by ControlRisks, a global consulting firm (Wood, 2013, p. 7).

In particular, Bulgarians became more united in their opposition because the exploration area in the Northeast is the country's most fertile agricultural land: The region ("the granary of Bulgaria") produces a very large share of wheat and other farming crops and contributes greatly to exports. Bulgaria is, like Romania, predominantly rural. Bulgarian agriculture holds 19 percent (Romania's even 31 percent) of total employment, compared to the EU-28's average of five percent (European Commission, 2014a, 2014b).

Farming communities fear water and ground contamination and industrial development by (foreign) energy investors as a threat to their overall livelihood, not just as a general environmental concern. Legislative and regulatory frameworks were seen as inadequate, full of gaps, and unclear in regard to the fracking method. Among the deficits was the fact that extraction laws do not give public stakeholders specific rights to get information, file requests and complaints, or legally challenge decisions. Most environmental restrictions were at the government's discretion. Limited legal means combine with generally low trust in due process 
of law and the judicial system. Moreover, Bulgarian law does not give a landowner rights to sub-surface mineral resources. The state is the exclusive owner of natural resources and thus can grant concessions without giving the public, the communities, and the landowners a say in the permit process. Questions of transparency and participation in decision-making mobilized people quickly. In particular, they felt politicians had been involved in secretive backstage agreements with foreign companies. In a country burdened with corruption, graft and political scandals, people assumed the worst. They found everything related to the issue of concessions to foreign companies very opaque. The response was negative.

At the same time, Bulgaria's established domestic energy sector was less than enthusiastic about the promise of energy supply alternatives and the entry of foreign companies. Both the nuclear and the renewable energy industry have vested interests in the status quo. The gas industry seemed more devoted to gas pipeline projects, whether South Stream (Gazprom) or its rival for nonRussian gas imports from Azerbaijan, the Nabucco project. The general business community also showed no excitement.

\section{Symbolic fight: Bulgaria between East and West}

Most investors competing for Bulgarian shale gas concessions were American companies. Chevron was the most prominent, and it received open and prominent help from the U.S. government. Remarkably, in summer 2010 U.S. ambassador James Warlick engaged very publicly at events and in the news media for Chevron's interests, whose managers were allowed to present their plans directly to prime minister Boyko Borisov and other high-ranking officials (Novinite.com, 2010). In interviews to newspapers and on $\mathrm{TV}$, Warlick continued to advertise the economic benefits of shale gas and the promise of investment and jobs creation by U.S. firms such as Chevron, trying to create a more positive opinion climate.

At the height of public protests, Warlick warned in media interviews that Bulgaria should think twice whether it really wanted to chase Chevron away (Novinite.com, 2012; Konstantinova \& Carroll, 2012). When the parliament had voted on the ban, Warlick stated in an op-ed that this would "have a profoundly negative effect on the future of its energy supply, investment climate, and economy." He criticized that "a full, informed, and public debate" weighing relative risks, cost and environmental impacts of energy sources should have taken place, but did not. The country had a "vacuum of information" about the pros and cons. He also said that "certain groups have a vested interest in maintaining dependence on costly imported energy" (Warlick, 2012). He reiterated these arguments in many media appearances.

From 2010, the U.S. ambassador showed such active and even pushy participation in Bulgaria's internal debate that he came to look like the father of U.S. firms' interest in the country. Energy minister Traikov felt in late 2010 he had to reprimand the diplomat publicly for complaining that Chevron had not yet received a permit. Traikov also claimed it was he, not Warlick, who brought the company in: "Why did Chevron come at all? Because when I visited the US, I went and talked with them, even though the US embassy had told me, don't talk to them, they are a huge company and are not interested in Bulgaria" (Novinite.com, 2010b).

Warlick's activity received mixed echoes, all the more because Warlick's interventions looked like Washington pressure serving corporate interests. For example, Kassabov (2012), in an editorial for Novinite.com, called Warlick's interventions "undiplomatic behaviour." He described the U.S. ambassador's actions a "consistent campaign of pushing Chevron in the center of public attention" and "staunch preaching of the company's interests - at times patronizing and disrespectful of the very laws in Bulgaria." Kassabov opined that a new dependence on U.S. firms like Chevron would be no better than one on Gazprom. Bulgaria could still be "ruined" by foreign corporate and geostrategic interests.
The impression that Washington was putting Bulgaria's government under heavy pressure was strengthened when U.S. Secretary of State Hillary Clinton visited Bulgaria in early 2012. It was perceived that Clinton was "lobbying" for Chevron's interests and for Bulgaria's break with Russian dependence (Euractiv, 2012b; Kassabov, 2012). Clinton also sent "energy tsar" Richard Morningstar, U.S. special envoy for Eurasian energy, on a mission to Sofia for talks with policy-makers "about how we can be more helpful in protecting your environment and advancing your energy security goals" (Euractiv, 2012b; UPI, 2013).

Those friendly to U.S. investment were quick to suggest that protests were orchestrated by Russian interests. On TV, energy minister Traikov opined that a well-financed large-scale PR campaign was behind the anti-fracking campaign - obviously hinting at Russian gas monopolist Gazprom. "A motivated elite" had misled people. "Those who protested and those who negotiated with us were fully aware of it," he said. In order to explain the movement, one should look "in the direction of money" and "who is to benefit and who is to lose" (Novinite.com, 2012c). In February 2012, a "Movement for Energy Independence" (DEN) was initiated by experts who insisted that Gazprom had manipulated Bulgaria into imposing the shale gas ban (Novinite.com, 2012d).

One of the founders, Ivan Sotirov, who is linked with the centreright Union of Democratic Forces (UDF), published an internationally spread editorial in the Trud newspaper. Under the headline, "Russian Lobby Against Shale Gas," he called the "pseudocivic pressure" a disinformation campaign "built on cheap manipulations and lies" and "an attempt to masquerade a political issue as purely ecological." He felt reminded of Cold War era Communist- organized "awful anti-American and anti-imperialist events." He went on to expose opponents as people linked to a domestic "energy mafia" (meaning state-owned BulgarGaz and the strong nuclear lobby) as well as Russia and Gazprom's South Stream pipeline project, concluding that

after 22 years of democracy Bulgaria's politics continues to be dictated by pro-Russian oligarchic circles. Hiding behind nationalistic and ecological rhetoric, they have prevented entry of any single serious strategic Western investor. The question is how long it takes until somebody will finally stop them. (Sotirov, 2012, author's transl.).

For many, the issue became framed as a question of whether Bulgaria wanted to side with the U.S. or continue its traditional ties with Russia. Political elites, parties and civil organisations split along the lines of pro-Western or pro-Eastern camps. Environmentalism became linked with anti-American and anti-bigbusiness positions. In one insightful commentary, TV journalist Boyko Vassilev analysed:

The battle wasn't really about shale gas itself. Gas - indeed, energy as a whole - has long [been] a stand-in for the oldest Bulgarian national question: Russia or the West? [...]

Same old battle, the one Bulgarians have repeated for 130 years. ProRussian and pro-Western arguments are dressed in different clothes to apply to every national issue, ancient or modern. Instead of paying attention to each other's environmental or economic points, the fight becomes Gazprom vs. Chevron, Russian lobbyists vs. American lobbyists. Nobody wanted to exchange, let alone change, views; people simply did not listen to anything that displeased them. It seemed less a policy debate than a matter of religious belief.

In all that fuss, few bothered to ask the geologists. They had some smart things to say on both sides, but their insights were met with battle cries. "Weren't you a consultant for Texaco?" "Why should we listen to someone who was educated in Moscow?" Amusingly, both sides complained that the public was being shielded from their arguments and only their opponents were being heard.

Ultimately the anti camp prevailed, with the help of two mighty forces that champion online campaigning and are increasingly important in Bulgaria: environmental activists and anti-globalists. The 
former, who make up a sizable and intelligent chunk of urban youth, added shale gas to their many causes almost automatically. For antiglobalists it was just another reason to denounce big politics (the United States) and big business (Chevron). (Vassilev, 2012)

Thus, the shale gas question and foreign investor engagement was absorbed as a symbolic issue by both traditional political interests and a new, broader coalition of socially mobilized groups. The shale gas issue did not stand on its own but was enmeshed in much larger controversies about the country's politics and future.

\section{Communication failure}

A puzzle about the hot debate remains. Politicians and NGOs battled it out, with a number of experts on both sides, the nuclear industry (negative on shale), and U.S. government officials taking part. But neither was there an effective public relations effort by the government, nor was there much of a longer parliamentary debate, nor communicative outreach by the firms which had come in to drill. A constructive direct dialogue between companies and the public, the environmentalists or local community organisations could not be observed. While Chevron was pushed in the limelight and continuously attacked offline and online, it only issued a few lame press statements and did not open dedicated online channels until 2012 (see illustrations). "What was striking," the Polish think tank OSW noted, "was the fact that the public debate was not joined by representatives of the companies which had been engaged in prospecting for shale gas in Bulgaria" (Daborowski \& Groszkowski,

Figure 2. As Chevron practically has no other operational interests in Bulgaria other than shale gas, its country website www.chevron.bg is exclusively devoted to the subject of unconventional resources. On its Twitter channel ChevronBulgaria,

the firm tweets almost daily - though not with Bulgarian news but rather information on Romania's or other international developments on shale gas. The channel's first tweet went online in October 2012.

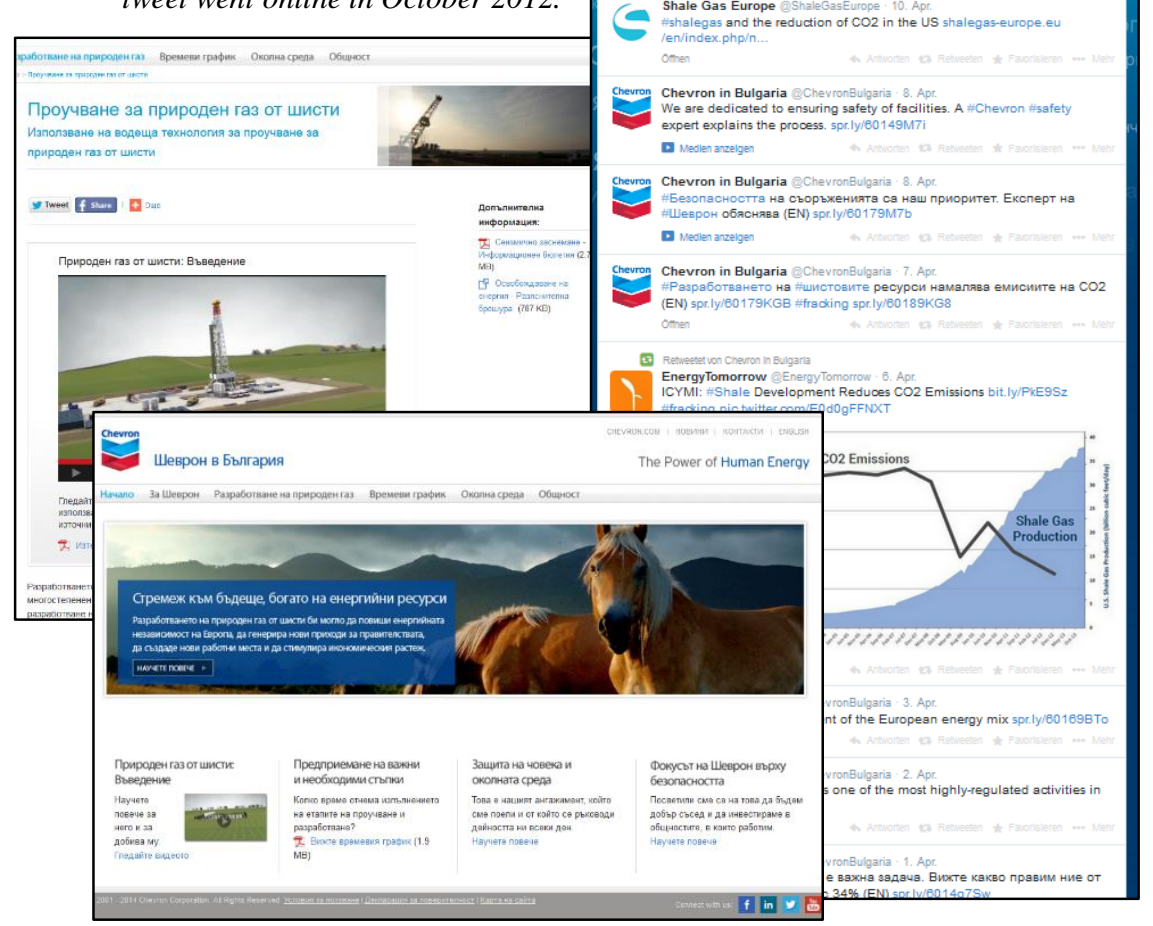

2012, p. 10). Lack of quality information, dialogue and trust-building efforts for a more balanced debate made it easy for simple slogans to dominate the debate. It is plausible that the public then quickly turns negative on projects - particularly in a country where environmental laws and regulations are often honoured in the breach, no public consultation culture exists, and people are always ready to suspect corruption in any major deal between business and government.

Under scrutiny, these domestic dynamics look more influential than spooky geopolitical proposals that a new Cold War is raging and that Moscow is secretly steering protest movements. Shaffer (2014) offers that Gazprom uses "insidious" tactics; it supports "bogus environmental movements" and has "funded anti-fracking campaigns in Europe, including in Ukraine and Bulgaria, to slow Europe's development of local gas supplies."

U.S. energy expert Aviezer Tucker also holds "the mark of outside influence is clear: In Bulgaria, there are rarely demonstrations of any kind" (2012b), assuming that Bulgarian civil society protest could not have risen quickly and effectively without external guidance, media power, money and logistics. He interprets rising environmentalism as a Russian-controlled "mobilizing ideology." Gazprom, he proposes, knows the languages, cultures and politicians in Southeastern Europe, and knows how to play, rather than ignore, the emergent civil society. "Doing business exclusively with the politicians and ignoring civil society is a mistake Gazprom has not made," claims Tucker (2012a), and shale supporters and foreign investors woke up too late as "public perception already had been dominated by myths and misconceptions about hydraulic fracturing, courtesy of Russian-financed public-relations firms" (Tucker, 2012a).

It can be confirmed that public perception was framed negatively in the absence of counterbalancing pro-shale communication, but whether that happened "courtesy of" Russian influence is far more questionable and without real evidence. Rather, Bulgarian NGOs and green politicians evidently used and spread information from other international sources, particularly other European and American anti-fracking organisations and media.

Where such voices are probably right is that investors, particularly U.S. companies, have been blind to strategy adjustment in order to establish trust and win a social licence. Perhaps that is due to a "terrible provincialism" among U.S. corporations, who, according to Tucker, send executives

into a country they basically do not understand. They then conduct business through intermediaries, fixers, shady people who know somebody in the power structure. Then money changes hands much like it would be in authoritarian countries in the Middle East, and the corporations expect to start drilling and concentrate on technical problems under the ground. Then, suddenly, out of the blue, the corporations make this startling discovery: They are operating in Europe and not the Middle East. Some of the politicians may be corrupt, but they still need to win largely fair democratic elections. There is civil society and there is free media that does its job exposing corruption and criticizing government 
decisions. [...] Had the corporations spent half a minute realizing where they were, they could have hired area experts who know the languages and the histories and some credible locals with patriotic credentials, not the shady intermediary types and try to explain to society and the media what and why they are doing what they are doing and what are the potential advantages to society and the politicians for whom people vote.

There is this false universalist mentality that the world can be run by MBAs and engineers who have universal models that can apply everywhere and so they do not need to know anything about local conditions and can ignore civil society. This is nonsense that costs money. [...] [T] he cause of energy independence will need to be advanced by local political and social movements and by diplomats who do know languages and study foreign cultures. (Sahraoui, 2012)

Indeed, at ground level, there was no attempt to build a pro-shale coalition with social credibility, and diplomatic interventions from the U.S. seemed to hurt rather than help the cause in Bulgaria.

\section{Will Bulgaria's ban stay?}

After the May 2013 parliamentary elections, the Bulgarian Socialist Party (BSP) formed a governing coalition with the liberal Movement for Rights and Freedom (DPS). In 2011/12, both parties had positioned themselves opposing shale gas. Given the polarized issue climate, it is unlikely that a lifting of the ban comes in the near future - unless the governing parties reverse course like the GERB party did in early 2012.

This does not seem to have practical energy policy value. While relations with Russia became strained during the Ukraine and Crimea crisis, the traditionally Russia-friendly BSP cannot but continue to concentrate on working with gas supply contracts with Gazprom and the South Stream pipeline construction project. Moreover, the incoming government immediately faced street protests on a variety of issues, including energy policies.

Upon taking office, prime minister Plamen Oresharski (BSP) said a review of the shale gas moratorium was not among his cabinet's priorities, but: "Of course, life is dynamic, and, where appropriate, will include new priorities and changing others" (24chasa, 2013). Was he testing the waters for a policy reversal?

Incoming environment minister Iskra Mihaylova (DPS) questioned the effectiveness of the ban. She commented in a TV interview that the ban was a temporary measure but not a final answer to the question of whether shale gas production could be possible and under what conditions. The ban was triggered by public mistrust of Bulgarian and EU laws, Mihaylova stated, and this public mistrust is the main problem. Environmental legislation, by contrast, in her view is good and strict enough to allow for preliminary studies of shale gas and guarantee safety. The country could afford to launch research to identify shale gas options and potential ecological and health risks - after gaining this information, the people would be free to say no to concrete projects, instead of an all-out flat no (Sega, 2013; Novinite.com, 2013).

Mihaylova's comments caused an uproar among fracking critics. Days later, she retracted and made clear that the ban would stay as long as citizens wanted it. She would obey, since citizens had made her minister. The cabinet did not plan to propose a repeal. She explained she had only shared "thoughts" she had developed while serving on a parliamentary committee (Ivanova, 2013).

Shale gas, for the near future, does not seem to be on the political agenda. The government focuses on a variety of difficult other energy policy projects - curbing end-user prices, working on the South Stream and potential other gas pipelines, efficiency and renewable energy matters. One key factor for future development in Bulgaria may be what happens in neighbouring Romania, which has exited from a 2012 moratorium and is now actively supporting shale gas exploration. Bulgarian anti-fracking activists are closely monitoring this and protest against operations at the borders.

\section{Romania: Exit from a Moratorium}

Romania's energy sources are fairly diverse - from coal, oil and gas to nuclear (two reactors), hydropower and wind. Because it has substantial domestic gas and oil supply and a tradition of 150 years of an oil and petrochemical industry, Romania's import situation is very different from Bulgaria's.

Gas imports are almost completely Russian, but gas imports make for only 17 percent of Romanian gas consumption (SGE, 2013a). The lion's share is locally sourced. At the moment, natural gas is the country's most important energy resource, accounting for over 30 percent of all energy resources used in Romania (Daborowski \& Groszkowski, 2012, p. 22). The country is the largest gas producer in Central Europe; the problem lies in continuous and fast decline of reserves, expected to run out in the next 15-20 years (SGE, 2013b). High gas prices add to the challenge.

The country is therefore heavily involved in the gas pipeline politics of the region and links to Asia, just like Bulgaria. It is considering its options to avoid an ever-increasing reliance on Russian gas imports.

Discovery of substantial unconventional gas deposits has opened a prospect of regaining domestic production strength and economic growth fuelled by cheaper energy, in turn making Romania attractive to foreign investors. Interestingly, some potential had been known to state-owned gas producer Romgaz. Romgaz communicated in 2012 that it had successfully tested fields in Transylvania in the mid-1990s, using hydraulic fracturing techniques with U.S. know-how (Pirvoiu, 2012).

According to a 2013 study by the European Centre for Excellence in the Field of Natural Gas (Centgas) as a part of the Romanian National Committee of the World Energy Council, Romania's unconventional gas resources could present an alternative for the future energy mix. It could improve Romania's energy selfreliance, even leading to independence. The country's gas exports could contribute 1.5 percent to annual GDP. Gas prices could decrease by over 30 percent in the long term. Production could create many jobs and much tax income (SGE, 2013b).

The U.S. Energy Information Administration estimated in 2012 that Romanian's ground contained 1.4 billion cubic meters of technically recoverable resources. If true, Romania has the third-largest deposit in Europe behind France and Poland. Several areas in Romania seem to have good potential to develop unconventional gas: the Oriental Carpathian Mountains, the Moesian Platform, Southern Dobruja, and the Bârlad Depression (SGE, 2013b).

Despite many uncertainties, these potentially large deposits have drawn international investors. One of the most interested companies is American supermajor Chevron. It obtained four prospecting licences, three in Dobroesti in 2010 (close to the Bulgarian border) and one in the Barlad region in 2011 (Daborowski \& Groszkowski, 2012, p. 24). Among Chevron's potential rivals are Romania's two largest gas producers, state-owned Romgaz and privatized oil corporation Petrom, now owned by Austrian OMV, also plans to enter the game (Marinas \& Patran, 2013). Hungary's MOL, Canada's East West Petroleum (EWP) and other firms also showed interest.

\section{Communication failure}

The new subject unleashed political controversies with many similarities to Bulgaria. In fact, what happened in Romania can be interpreted as a spillover from Bulgaria's events. Until the end of 2011, Romania's centre-right government of prime minister Mihai Razvan Ungureanu took a supportive position toward the exploration and potential production of shale gas. Like Bulgaria's, the Romanian government handed out exploration licences without much publicity. 
Government public communication about shale gas benefits and risks was essentially nil. This failure to proactively discuss pros and cons, and a too-late, reactive attempt to explain decisions only after protests and intense negative media coverage had reached a peak, went on to wreak havoc on the government. It met already high social discontent over other issues, especially the state's austerity policy, budget cuts and tax increases. The shale gas issue entered discourse quite suddenly. Before 2011, the issue was practically not on the country's public radar screen. With the public's "complete informational blackout", the shale gas issue had "an unfortunate debut" and became subject to "political footballery" (Gusilov, 2012, p. 5-6).

The government's licensing practice without communication brought about massive citizen protests. Political instability seemed big enough for U.S. investor Chevron to declare in April 2012, only days after its concession agreement went into force, that it would not have drilling operations but only seismic data surveys in the next 12 months (which of course is the natural process anyway). Country manager Tom Holst stated:

We recognize the importance of sharing facts on the exploration technologies, that are standard for oil and natural gas, and exploitation technologies for releasing natural gas from shale formations, which are new to Romania, but have been safely used for decades in many locations. In the months ahead, Chevron is committed to focus on creating a dialog with the population and policymakers, in order to clarify both the concerns as well as many benefits associated with this clean and efficient energy source. (Chevron, 2012)

That same month, the government collapsed over a parliamentary no-confidence vote introduced by opposition Social Democrats. They accused the government of authorising shale gas exploration without adequate scientific and regulatory oversight (BBC, 2012a; Economist, 2012). The Social Democrats took over, forming Romania's third cabinet in this year. In May, the new government under prime minister Victor Ponta imposed an administrative six-month moratorium on the exploration and exploitation of shale gas. Officially, the government declared it was waiting for EU studies on environmental risks to be concluded. The moratorium expired by end of 2012. It was not renewed.

In January 2013, U.S. energy firm Chevron obtained permission to go forward with shale gas exploration. Local authorities had no option but to grant permits once the moratorium had expired. By March 2013, the government had made a full U-turn and came out in support of shale gas. Politically, it was a broken promise.

This led to even more protests, which the government decided to face down and even suppress by sending riot police to local hot spots, including Chevron locations. Meanwhile, Chevron began on-site village meetings to present and discuss plans with local residents. Nationally, it said in media statements that it "respects the freedom of expression and individual liberties" and that

Chevron understands that communities have expectations and concerns surrounding the development of natural gas from shale, and the company will continue to address these through frequent consultations with local stakeholders, and by respectfully addressing them through open and honest dialogue. (Molnar, 2013a)

The Ponta government took a gamble with public opinion. A Eurobarometer survey reported in January 2013 (based on autumn 2012) very low support for prioritising shale gas efforts, while a majority of respondents expressed concern should a shale gas project start in their neighbourhood. Clearly lower percentages than the EU-27 average, also lower than in Bulgaria, agreed that European rather than national approaches should prevail (see Table 1).

A Romanian April 2013 poll reported that shale gas was seen as a threat by a plurality of Romanians. The survey found 42 percent believed shale gas drilling poses a danger to the environment and people, while 22 percent did not. 16 percent said they could not judge and comment upon dangers. Finally, 20 percent of respondents said they had not yet heard of the issue, the ARP polling firm reported (2013, p. 34).

Visan (2013) ), of the Romanian Energy Center, comments that public opinion has no real profile because the subject is a novelty. Most citizens lack substantial information. Where public opinion is or will go is not clear. This stands in contrast to a political elite where, Visan suggests, currently an apparent consensus exists on the economic and strategic benefits of shale gas. He concludes: "The state and civil society are not on the same page" (p. 9).

\section{Table 1. Eurobarometer (2013) public opinion poll}

Q21. Thinking about the next 30 years, which of the following energy options do you think should be prioritised now in [country]?

\begin{tabular}{|c|c|c|c|c|c|c|}
\hline & 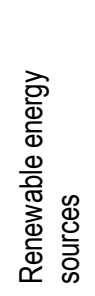 & 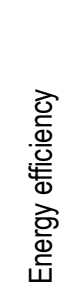 & 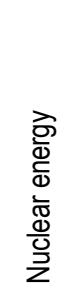 & 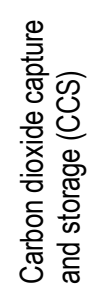 & 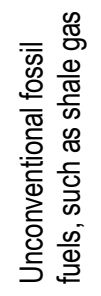 & 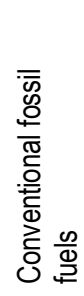 \\
\hline mania & $49 \%$ & $21 \%$ & $16 \%$ & $21 \%$ & $9 \%$ & $10 \%$ \\
\hline aria & $45 \%$ & $29 \%$ & $28 \%$ & $10 \%$ & $8 \%$ & $7 \%$ \\
\hline$U 27$ & $70 \%$ & $28 \%$ & $18 \%$ & $12 \%$ & $9 \%$ & $8 \%$ \\
\hline
\end{tabular}

Q22. If a shale gas project were to be located in your neighbourhood, do you think that you would be...

\begin{tabular}{lccccc} 
& $\begin{array}{c}\text { Very } \\
\text { concerned }\end{array}$ & $\begin{array}{c}\text { Fairly } \\
\text { concerned }\end{array}$ & $\begin{array}{c}\text { Not very } \\
\text { concerned }\end{array}$ & $\begin{array}{c}\text { Not at all } \\
\text { concerned }\end{array}$ & $\begin{array}{c}\text { Don't } \\
\text { know }\end{array}$ \\
\hline Romania & $\mathbf{4 2 \%}$ & $31 \%$ & $14 \%$ & $\mathbf{7 \%}$ & $\mathbf{6 \%}$ \\
\hline Bulgaria & $50 \%$ & $28 \%$ & $10 \%$ & $8 \%$ & $4 \%$ \\
\hline EU 27 & $40 \%$ & $34 \%$ & $13 \%$ & $7 \%$ & $6 \%$
\end{tabular}

Q23. Do you totally agree, tend to agree, tend to disagree or totally disagree with the wollowing statement: Harmonised and consistent approaches should be developed in the EU to manage unconventional fossil fuels extraction, such as shale gas.

\begin{tabular}{lccccc} 
& $\begin{array}{c}\text { Totally } \\
\text { agree }\end{array}$ & $\begin{array}{c}\text { Tend to } \\
\text { agree }\end{array}$ & $\begin{array}{c}\text { Tend to } \\
\text { disagree }\end{array}$ & $\begin{array}{c}\text { Totally } \\
\text { disagree }\end{array}$ & $\begin{array}{c}\text { Don't } \\
\text { know }\end{array}$ \\
\hline Romania & $\mathbf{2 4 \%}$ & $\mathbf{2 6 \%}$ & $\mathbf{1 1 \%}$ & $\mathbf{2 9 \%}$ & $\mathbf{1 0 \%}$ \\
\hline Bulgaria & $19 \%$ & $38 \%$ & $13 \%$ & $23 \%$ & $7 \%$ \\
\hline EU 27 & $28 \%$ & $33 \%$ & $13 \%$ & $17 \%$ & $9 \%$
\end{tabular}

Field research conducted in September 2012 in Bulgaria by TNS BBSS (1003 adults 15+ yrs) and in Romania by TNS CSOP (1002 adults). Polled in the EU27: 25,525 adults.

Meanwhile, the Romanian government slowly began to reconsider its poor communication strategy. In April 2013, the National Agency for Mineral Resources (NAMR) began a year-long information effort on shale gas, a pilot project campaign half funded by the EU. Notably, the overall budget was a meagre $€ 121,000$. The NAMR explains that it aimed to inform "in a neutral way to ensure a balanced exchange of views." The budget would mainly go into a website (www.infogazedesist.eu, launched in July 2013) and diverse publications, and online consultation, and the setup of two public hearings in January 2014, one for each region where activities on shale gas are planned (Barlad and Dobrogea/Constanta) to bring in various stakeholders: central and local public authorities, NGOs, the general public, experts, academia and the media. They were to generate a debate on online consultations' findings, to "create the opportunity for the community to express certain concerns," and "build confidence between people and authorities in charge with implementation of the projects." The Agency put together a road show, brochures, flyers, press releases (Baciu, 2013). 
If participation at the campaign website discussion forum is an indicator of success, then this success is absent. The ongoing online survey has only been used, as of this writing (April 2014), by 144 users. The question "Do you agree to start exploration to identify whether there is shale gas in Romania?" was answered by 88 percent with "no." The forum had only 178 members, with 45 posts (Infogazedesist.eu, 2014). This is laughable in contrast to the broad online activity by protest groups and media coverage of antifracking protest action during the NAMR campaign's period.

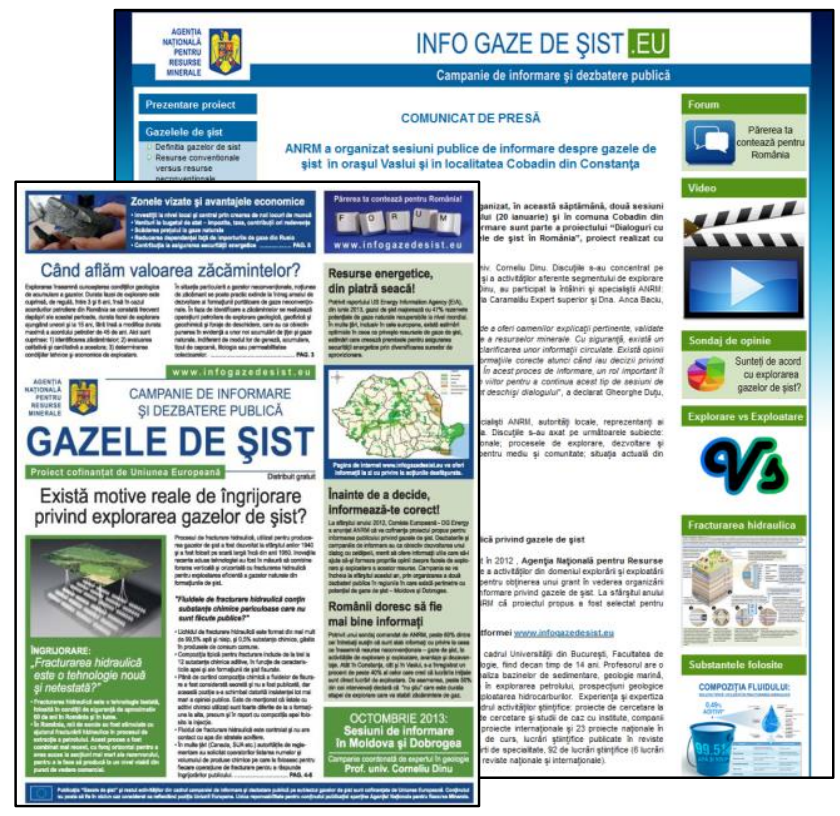

Figure 3. The EU-co-funded government "Campaign for information and public debate": An NAMR flyer and the website www.infogazedesist.eu. Flyers were distributed to households in shale gas exploration areas in September 2013 (Baciu, 2013).

The Agency had a plausible rationale: People expect and demand authorities to fill the information gap. NAMR reasoned that

in Romania, the general opinion upon shale gas issue is characterized by scepticism and suspicion, mainly, because is not sufficiently explained and the local population and local authorities lack balanced information in terms of opportunities and threats related to shale gas exploration and exploitation (Baciu, 2013).

The Agency reported findings of July 2013 representative local public opinion surveys and focus groups. Over 60 percent of respondents said they felt poorly informed about unconventional resources, the difference between exploration and exploitation, advantages and disadvantages. Over 40 percent believed that initial works were about production, not exploration. Over 50 percent said they did not know how long exploration takes (3-5 years). Over 65 percent said they did not know about potential risks during exploration, and over 50 percent said the same about disadvantages of the later exploitation phase. Over 40 percent could not name advantages of shale gas. 47 percent stated that there had been no accurate public information. About half believed that it was mainly the local authorities's duty to inform citizens; others expected it from various national government offices (Baciu, 2013).

The Agency's campaign is, however, hardly "neutral" as it claims. Its "key messages" clearly aim at "mobilising support" and include a range of pro-shale advocacy arguments, i.e. that the projects will generate local revenues, contracts for local firms, employment, better infrastructure, or plainly, "Romania will no longer be dependent on the Russian gas" (Baciu, 2013).

\section{Mr. Ponta's U-turn politics}

The reversal of the reversal of shale gas policy points, like in Bulgaria's case, to the eminent political risk investors face in Southeast Europe. Romania has difficult and turbulent politics: Its party system and coalition governments tend to be instable. Alliances form and break. The year 2012 saw two governments collapse, and the end-of-year election totally shifted party strengths. Election turnout is as low as public trust in political institutions and leaders, and citizen dissatisfaction is high. Constant elite power struggles in 2012 even led to a constitutional crisis. The public is very aware of widespread corruption. Romania is, as its neighbour Bulgaria, under special EU monitoring based on concerns about corruption, due legal process, judicial independence and implementing promised reforms.

A key factor in politics has been public anger at the austerity policies required by international aid to Romania during the financial and economic crisis in 2009. Cutting the budget, public services and civil servants' salaries, as well as tax increases, were so unpopular and resulting in partly violent protests that prime minister Emil Boc resigned in February 2012. His successor Mihai Răzvan Ungureanu lasted only two months. In summer 2012 local elections and then the December 2012 general elections, Social Democrat Victor Ponta was able to profit from the turbulences, winning with his centre-left Social Liberal Union an absolute majority of nearly 60 percent, crushing other parties (BBC, 2012b).

It is in this context that energy policy-making of the current government and the ongoing public controversies must be seen. Local protests against fracking had begun in early 2012 and merged with anti-government protests of a general nature. The shale gas controversy won public attention through linking with other protest and civil unrest - against the backdrop of a hot election year.

"In an intense political rivalry," notes Huseynov (2013), "none of the political forces wanted to take responsibility for the controversial shale gas explorations and risk losing voters." Ponta's centre-left electoral alliance promised to revoke the concessions given to energy companies and quickly install a moratorium. This was popular and populist, and Ponta rode the green wave. Upon taking office, the government made good on the promise. Shale gas opponents applauded. Environmentalist NGOs celebrated Ponta with a "Young Ecologists' Hope" Green Award in summer 2012 (Guvernul Romaniei, 2012).

The NGOs should have looked twice at their green hero. Soon enough, the premier stated that Romania was to move along with EU neighbours: "We want to be neither the only country to accept shale gas tapping nor the only one to oppose it." Over time, technology and ecological standards would evolve. Romania would take a stand once better knowledge was available (Euractiv, 2012).

A legislative initiative from Ponta's party to go further and prohibit fracking by statute was halted by the government and the Romanian Senate in June. It signalled that the new prime minister Victor Ponta wanted to leave his options open until after the autumn elections (Euractiv, 2012). The moratorium, concludes Gusilov (2012), was thus likely to be based on a desire to cool down the political temperature before the upcoming December elections, and to buy time (p. 4-5). By the end of 2012, it was already expected that the Ponta government would shift course. Indeed, it was preparing to do so. One clue: In October, the government's National Agency for Mineral Resources (NAMR) applied for EU funds for a shale gas information campaign in the two regions where concessions had been given to start in spring 2013 (Bacius, 2013). The year passed, and now Ponta stated he would support shale exploration -- pointing to energy prices as a factor for the economy's competetiveness, Russian imports and energy independence as fundamental issues. He would assume responsibility for this "unpopular" policy (Stroe, 2013). 
Vişan (2013) explains the U-turn by two factors: political and economic. After the electoral season was over, the anti-shale gas position seemed untenable in both ways. The government now enjoyed solid large parliamentary majorities without any need to cater to green party or NGO interests. It believed no large-scale protest effort could be sustained for long. In addition, the government wanted to avoid conflicts with foreign investors, especially those from the U.S. like Chevron. A deep strategic partnership with Washington is key in Romania's diplomacy, and the U.S. expects - and pushes for - a cooperative attitude toward U.S. firms. Economically, Ponta's government was "under pressure to deliver, given the hopes for better economic prospects" which its electoral supporters really want. In energy economics, it became clear in 2012-13 that the EU-backed Nabucco pipeline project would fail. Nabucco had held the promise of delivering non-Russian gas. Its failure meant that future imports can only come from Russia (Vişan, 2013, p. 6).

This is not desirable for the Social Democrats. Their sister party in Bulgaria, BSP, may be friendly to Moscow, but the left in Romania keeps more distance and does not have BSP's political, business and historical ties to Russia or Gazprom interests. In respect to energy policy and Russia, the two Socialist parties in government have little in common (Assenova, 2013).

Ponta's about-face infuriated many of his electoral supporters. He seemed just like another politician who was breaking his word, letting down and betraying the people who had trusted him. Those who had been angry with Ponta's predecessor government over licensing shale gas firms now were angry at him for returning to the out-voted coalition's policy. This mobilized anti-fracking campaigners who once again could couple with anti-elite sentiment.

The campaign also resonates with a general scepticism about the legitimate role of business in society and natural resources use. As in Bulgaria, critical issues lie in the legal principles of natural resources exploitation. Romania's constitution lays down that mineral resources belong to the public domain, i.e. the state, not to landowners. This means the government gives permission rights to explore and extract to companies, while landowners cannot decide what happens with their lands. This may incite Not-in-myback-yard (NIMBY) resistance. Private property owners have a right to compensation but cannot decline right-of-way and drilling operations. Operationally, this works under a normal mining regime, not under a specific law for unconventional resources (Munteanu-Jipescu, 2013).

The essence of decision is national, not local. Conflicts between local and national public interest can and do arise, and they have been a key driver of confrontation. From a national view, unconventional gas operations could have large economic benefits for Romania. Locally, the (environmental) cost may outweigh benefits. While there may be some visible benefits in construction and services near a drilling site, it is far more important that by law, royalties and taxes collected will be income for the state, not municipalities. The question of a community dividend is wide open.

\section{Traits of the anti-shale gas protest movement}

Since 2012, Romania's ongoing series of protest action and demonstrations against exploration of shale gas evolved from single local events to a national scope. As elsewhere, the main issues are water and ground contamination and other environmental risks, as well as fears about earthquakes. Online and social media networking has been a catalyst, but the more visible part were street demonstrations. As in Bulgaria, Chevron came to be singled out as a target with anti-American overtones; but some activists also claimed they were "not fighting Chevron, they are fighting the government," criticizing a "lack of transparency and information" on planned exploration programs (Karasz, 2012).
Perhaps rightly so. Groszkowski \& Daborowski (2012) point out that it was the government, rather than Chevron, which "strangely maneuvered not to disclose its exploration licence agreement with Chevron, even though the American company suggested unveiling the document in order to stop the rumours of corruption and conspiracy theories." Demonstrations involving tens of thousands of participants in dozens of locations across the nation were not just about environmental safeguarding but also very much about respecting the will of local communities and transparent decision making.

In the past two years, regional centers have been the city of Barlad and the Pungesti village in Eastern Romania where Chevron is operating. Protesters have used social media, Internet TV, and online petition campaigns, they have organized marches, human chains, roadblocks, and protest camps. While most protests are peaceful, some have turned into violent clashes with police, leading to arrests, injuries and complaints about police brutality. Some involve local political controversies where politicians and local party branches get engaged with both pro and anti-shale gas sides - playing local politics and competing for support (Vişan, 2013; Revolution News, 2012; Patran, 2013; AFP, 2013).

In Pungesti, a tiny community but now internationally known because of TV coverage of the protests in autumn 2013, Chevron was forced to suspend operations for several months. After weeks of site blockings and riots, Chevron removed personnel and equipment from the site. In November, in an unusual 45-minute video interview with HotNews.ro, Chevron country manager Tom Holst explained the firm's efforts at length. This included meetings, publications about the technical process and voluntarily disclosure of frac-fluid composition. He emphasized the local approach:

[W] went door-to-door and talked to people face-to-face, we will continue to do it and we have sent delegations, there has been a trip to Poland so that they may talk to members of a community and see such operations with their own eyes, so that, coming back, they may tell the neighbours what they have seen. This is how we communicate. [...] [W] hat we found in the door-to-door campaign in August and September was very interesting. The teams visited four local communities, more than 600 households, and discussions took 20 to 80 minutes. This is a good length of time for dialogue, for providing information. In only two of the 600 households people said "sorry, no, we have enough information". What I can see in this is that people want to understand and want to receive information.

[...] [in Dobrogea] our method of communication was to go to the local mayors, we went to about 15 mayor's offices in small communities, we had question and answer sessions and provided a presentation. Today, for instance, in such a community, at the local mayor's office, there will be a presentation, academics will come to speak about technology-related issues and there will be a Q\&A session. This is how we believe we can best communicate to the people and our experience tells us that we will need those communities and will continue to focus our activity on those communities. (Pantazi, 2013)

Holst stated Chevron wanted to be "a good neighbour, which means social investment." This meant, for example, donating an ambulance to a hospital or a medical caravan visiting villages; sponsoring a programme to keep underprivileged youths in school; improving roads or drilling drinking water wells (Pantazi, 2013).

What he did not say was that not always were the door-to-door visitors, publications or gifts welcomed. In many reported cases, Chevron contractors were threatened by mobs, chased away or could only conduct their work under heavy police protection; the "dialogue" became to look absurd. A British TV team reported:

Stories abound of Chevron representatives attempting to hand out yoghurts and t-shirts on the village high street months earlier, crude acts of poorly-calculated PR that backfired spectacularly, yoghurts thrown back in disgust at the people distributing them. (Wickens \& O'Brien, 2014) 
Local defiance in the remote rural areas does not look like the green activism in the protest camp at University Square in Bucharest. In the poorest corner of Europe, incoming engineers and their high-tech fleets engage in a culture clash. Subsistence farmers and conservative villagers are "the unlikeliest of eco-protesters, a lifetime of hardship engraved on their faces" (Wickens \& O'Brien, 2014). They would rather stay poor, live off their little land, social aid and cash from relatives working abroad than to compromise water and fields. They want to be left alone and stubbornly resist Chevron's "conversation grounded in scientific data" (Ilie, 2012).

In April 2014, Chevron resumed activity and began to build its first drilling rigs, again met by demonstrators and blockades (Novinite.com, 2014). The same month, cross-country protests culminated in a "Ziua Naţională de Proteste anti-fracking," or National Day of Protest Against Fracking, in 60 cities, with 150 NGOs and local groups participating. Most local action gathered only hundreds, but they added up to thousands (Herron, 2014).

One notable trait of the Romanian protests is the visible role of the Orthodox Chruch. Often, clerics have accompanied events with religious ceremonies, prayers and songs. Rural Romania is deeply religious, and many priests have sided with the shale gas opposition. To some, fracking seems a biblical challenge, and investors like the devil. One priest who is a central figure in the antifracking campaign, warned against "an invading army and foreign corporations; enemy chieftains and corporate managers; traitors and lobbyists" (Dale-Harris \& Ursulean, 2013). An Orthodox bishop spoke in one sermon of "diabolical plan [...] scouring the earth, poisoning the water, the springs created by God... This is a crime! A crime! A diabolical economic plan!" (Visan, 2013, p. 8).

Officially, the church recommends that priests and monks do not personally get involved with public protests so not to divide the Orthodox community. But while it does not take a clear pro or con position on shale gas, the church has pressured the state to provide complete and correct information to local communities about shale gas exploration consequences, and advises priests to demand this from government officials (Stroe, 2014).

As Vişan (2013) points out, this is the very first time since the fall of communism that the Romanian Orthodox Church has taken a stand on a secular issue together with civil society organizations (p. 8). The church thus joins "a heterogeneous movement whose environmental core is strengthened by opinion-leaders of leftwing, nationalistic, or anti-capitalist beliefs" and "disgruntled citizens who feel disempowered" and "a young generation of Romanians who are fed up with Romania's endemic corruption and lack of accountability of the current political elite" (p. 3).

As in Bulgaria, anti-fracking activism must be understood in a broader social movement context. It evolved with citizen dissatisfaction and moves to democratise politics. Social observers have noted that new mobilization (particularly of middle-class, educated young people and professionals) for various causes show an organized civil society has been forming in Romania.

As Presadă (2012) notes, many studies have tried to explain why Romanian society has not developed a protest culture comparable to other European countries - for example, by pointing to Romanians' long-nurtured culture of obedience and fatalism. To experts' surprise, the year 2012 would show a very different reality. Diverse groups came together, found common themes and leadership; new actors became visible; and "a new agenda crystallized following the protest experience" which centered on demanding more democratic public involvement and participation, government responsiveness, transparency, and accountability to citizens - all linked by an "awakening theme" (Presadă, 2012, p. 23-24).

As Stoica (2013) points out, the emergence of a new civil society still has to overcome many obstacles: the lack of a traditional associative culture and low citizen participation levels, feeble organisation, limited inter-group coordination and communication, and thorny relationships with state institutions which often do not respect civic rights. Outside of the party system, the government seldom takes NGO input into consideration in routine legislation and policy-making, Stoica finds. While groups may enjoy better access at the local level, at the national level it is limited. NGOs and the state "struggle to find a way towards a genuine dialogue."

In the shale gas case, obviously such dialogue has been wishful thinking. Ponta's party and allies were responsive and cooperative only as long as they were in opposition. The rift widened again once they took power. It is no wonder that mobilising against the state, rather than negotiating and subtle influencing, becomes a strategic choice. The anti-fracking movement linked with many groups and causes, ranging from anti-austerity to anti-corruption to anti-corporate and anti-globalization to environmentalism and conservation, especially in mining and extraction sectors.

One earlier case, the reopening of the Rosia Montana gold mine in Transylvania, had already sensitized Romanians for environmental issues in the extraction industry; it also increased cooperation and coordination among activist groups. Canadian investor Gabriel Resources had obtained a licence for Rosia Montana 15 years ago but found the project blocked by citizen resistance, politics and regulatory obstruction (Chiriac, 2014).

The environmentalists' campaign, centering on the use of cyanide and intransparency of government action, has often overshadowed the shale gas debate. Public protests, in autumn 2013 bringing 20,000 people to the streets of Bucharest, successfully pressured politicians to delay a necessary mining reform law. This was another major U-turn. With next elections around the corner, mining regulations are "a politically toxic issue," and "forcing the issue would have swelled the ranks of the protesters," states Maplecroft political risk expert Florian Otto, who sees many similarities to the shale gas issue (Otto, 2014).

Given that the Ponta government was already taking an unpopular stand on shale, opening up a second front was out of the question. One may conclude that the government enjoys low public trust across the field of natural resources policy.

Figure 4. "Shale gas war begins in Barlad" - cover page of the tabloid newspaper, Evenimentul zilei, 1 March 2013.

The paper reported on the march of thousands against shale gas exploration in late February. With dramatic imagery, the paper suggested that Russia is behind the demonstrations, undermining the effort to make energy independence a reality for Romania.

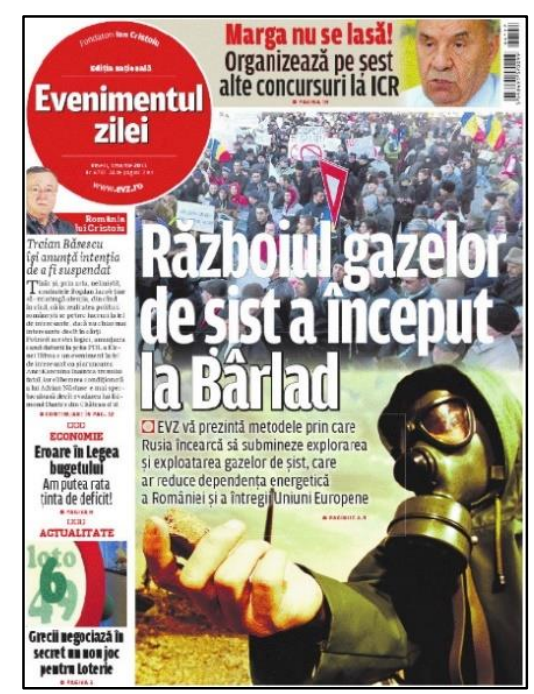

As in Bulgaria, the outburst of protests - and the seemingly well-oiled campaign machinery - surprised so many that all sorts of rumours and conspiracy theories spread about the "real" initiators. One rumour in the media indicated that the Orthodox Church - which strongly denied it - was trying to recover land that it had earlier allowed Chevron to use (România libera, 2013; Stroe, 2014).

Other media publicised the claim, that "a Russian hand" was at play: Moscow and Gazprom were attempting to block shale gas extraction to keep the country on imports (Evenimentul zilei, 2013, see figure 3). As in Bulgaria, solid evidence was missing. 


\section{Conclusions}

Bulgaria and Romania are very poor. They have structural energy problems, and they can ill afford to forego an economic stimulus and foreign investment. But no shale gas fever emerged like in Poland. A prudent, careful debate about technology impact assessment and environmental conditions also did not take place. In the deeply conservative rural heartland and in progressive cities alike, authorities and investors experienced a backlash unheard of before. The upsurge of protests has much to do with general rifts in society and the turbulent politics of these young democracies. Online and mass media lightened up with the controversy - it made a good story. NGOs and parties seized the opportunity to rally and mobilise a discounted public in a context of highly partisan competition and election politics. Politicians instrumentalised and, one may say, hijacked energy issues out of political opportunism and for symbolic purposes. Dogmatism was at play neither on the left nor the right (Groszkowski \& Daborowski, 2012).

Discourse, deliberation and choice are what a healthy democracy is about. Sensing that their governments - and shale gas firms - supplied none of these, the public responded in kind: It denied a balanced, constructive attitude. Shale supporters and companies underestimated or ignored the necessities of broad communication efforts. They learned the hard way that social acceptance has to be earned and cannot be guaranteed by top-down decisions anymore, and that wobbly political support can collapse.

The Bulgarian ban and Romanian moratorium were politically motivated and implemented without much thought to a coherent regulatory landscape. Neither government tried to work at the EU level toward a general policy on unconventionals. They could have influenced the European debate with credibility, given their direct exposure. Bulgarian and Romanian governments perceived the shale gas question as a purely domestic and political concern.

Stereotypical accusations that Moscow is behind anti-fracking movements seem too simple explanations - which is not to deny that Russia and Gazprom have great interests at stake and may exert influence where they can. The more complex explanation may be that Romania and Bulgaria are experiencing a new phase in democratic evolution. As a practical matter, the EU, the U.S. and Western foundations have invested for years in civil society capacity-building: training by Western NGOs in public communication techniques, civic participation skills and political organising. That investment may have finally paid off: Citizen groups now put the tools to practice. Not Russia but the West have enabled them - mirroring, coincidently, Russia's regular complaints that Western involvement is behind political opposition in Russia and the Ukraine. The new socio-political realities in Romania and Bulgaria may partly have been the result of a desired transformation.

Bulgaria and Romania now travel on different roads. It is not inconceivable that either or both reverse again. Local confrontations and the existence of the Bulgarian ban still hold considerable political risk for the Romanian government. On the other hand, if Romania successfully accesses its shale gas and develops it commercially, this may sway Bulgaria to follow.

\section{References}

\section{References Romania}

AFP (2013a, 31 Jan). Chevron gets permit to explore shale gas in Romania. IndustryWeek.com. Retrieved 15 Apr 2014 from http://www.industryweek.com/energy-management/chevron-gets-permit-exploreshale-gas-romania

AFP (2013b, 27 May). Romanians protest against Chevron shale gas plans. Retrieved 15 Dec 2013 from http://uk.news.yahoo.com/romanians-protest-against-chevron-shale-gas-plans180318775.html\#Zgs7LCG

ARP, Agentia de Rating Politics (2013, Apr). Piata politica. Sondaj de opinie national, barometru de opinie politica. Retrieved 16 Apr 2014 from http://ratingpolitic.ro/wp-content/uploads/2013/04/BarometruARP-Piata-politica-apr2013-presa.pdf

Assenova, M. (2013, 2 Jul). Bulgaria and Romania: pursuing energy security in a changing environment. Center for European Policy Analysis. Retrieved 16 Apr 2014 from http://www.cepa.org/content/bulgaria-and-romania-pursuing-energy-security-changing-environment

Baciu, A. (2013). Information campaigns on shale gas in Romania. Presentation. National Agency for Mineral Resources. Retrieved 18 Apr 2014 from http://www.romania-og.com/RomaniaOG/media/Site_Images/ContentPhotos/Intercontinental/6-Anca-Baciu.pdf

BBC (2012a, 27 April). Romanian government falls in no-confidence vote. Retrieved 15 Apr 2014 from http://www.bbc.com/news/worldeurope-17870304

BBC (2012b, 10 Dec). Romania election: Victor Ponta's ruling coalition. Retrieved 15 Dec 2013 from http://www.bbc.co.uk/news/world-europe-20656359

Chevron (2012, 2 Apr). Holding statement. Retrieved 16 Apr 2014 from http://www.naturalgaseurope.com/content/5720/Chevron\%20Romanian $\% 20$ Shales $\% 20$ Holding\%20Statement.pdf

Chiriac, M. (2014, 2 Apr). Frustrated gold mine company axes Romanians. Balkan Insight. Retrieved 16 Apr 2014 from http://www.balkaninsight.com/en/article/massive-lays-off-at-romanian-gold-mining-project

Daborowski, T. \& Groszkowski, J.(2012, Sep). Shale gas in Bulgaria, the Czech Republic and Romania. Political conditions - legal issues - perspectives. Ośrodek Studiów Wschodnich. Retrieved 13 Dec 2013 from http://www.osw.waw.pl/sites/default/files/shale_gas_in_bulgaria_the_czech_republic_and_romania_net_0.pdf

Dale-Harris, L. \& Ursulean, V. (2013, 21 Oct). Chevron suspends shale gas exploration plan in Romanian village after protest. The Guardian. Retrieved 16 Apr 2014 from http://www.theguardian.com/environment/2013/oct/21/chevron-shale-gas-exploration-omanian-pungesti

Economist (2012, 27 Apr). The Romanian government falls: Another one bites the dust. Retrieved 14 Apr 2014 from http://www.economist.com/blogs/easternapproaches/2012/04/romanian-governmentfalls?page $=2$

Euractiv (2012, 25 Jun). Romania leaves options open for shale gas development. Retrieved 15 Apr 2014 from http://www.euractiv.com/energy/romania-leaves-options-open-shal-news-513527

Eurobarometer (2013, Jan). Flash Eurobarometer 360. Attitudes of Europeans towards air quality. Report January 2013. Retrieved $16 \mathrm{Apr}$ 2014 from http://ec.europa.eu/public_opinion/flash/fl_360_en.pdf

European Commission (2014b). Agriculture. Member states factsheets: Romania. Retrieved 16 Apr 2014 from http://ec.europa.eu/agriculture/statistics/factsheets/pdf/ro_en.pdf

Eurostat (2013). GDP per capita, consumption per capita and price level indices - Statistics Explained. Retrieved 15 Dec 2013 from http://epp.eurostat.ec.europa.eu/statistics_explained/index.php/GDP_per_capita,_consumption_per_capita_and_price_level_indices

Evenimentul zilei (2013, Mar). Romania: 'Shale gas war begins in Bârlad'. Retrieved 14 Dec 2013 from http://www.presseurop.eu/en/content/news-brief/3478241-shale-gas-war-begins-barlad.

Gaydazhieva, S. (2013, 5 Apr). Wave of protests against shale gas in Romania, Bulgaria. Neurope.eu. Retrieved 14 Apr 2014 from http://www.neurope.eu/article/wave-protests-against-shale-gas-romania-bulgaria

Geophysics Rocks (2012, Apr). Shale gas key for Romania's energy independence. Geophysics Rocks! Retrieved 15 Dec 2013 from http://www.geophysicsrocks.com/2012/04/shale-gas-key-for-romania\%E2\%80\%99s-energy-independence/ 
Gusilov, E. (2012, Dec). Romania's shale gas strategy. Policy Brief 1. Romania Energy Center. Retrieved 15 Apr 2014 from http://sar.org.ro/wp-content/uploads/2013/01/Romanias-shale-gasstrategy.pdf

Guvernul Romaniei (2012, 5 Jun). Primul-ministru Victor Ponta a primit premiul "Tânăra speranță ecologistă" în cadrul Galei Green Awards 2012. Retrieved 14 Apr 2014 from http://gov.ro/ro/media/comunicate/primul-ministru-victor-ponta-a-primit-premiul-quot-tanara-speranta-ecologista-quot-in-cadrul-galei-green-awards-2012

Herron, D. (2014, 6 Apr). Anti-fracking protests in 60 Romanian cities call for fracking ban. Examiner.com. Retrieved 14 Apr 2014 from http://www.examiner.com/article/anti-fracking-protests-60-romaniancities-call-for-fracking-ban

Huseynov, A. (2014, 3 Apr). Prospects for energy independence in Romania: shale gas and beyond. New Eastern Europe. Retrieved 14 Apr 2014 from http://www.neweasterneurope.eu/articles-and-commentary/1169-prospects-for-energy-independence-in-romania-shale-gasand-beyond

Ilie, L. (2013, 27 Oct). Romanian farmers choose subsistence over shale gas. Reuters. Retrieved 18 Apr 2014 from http://www.reuters.com/article/2013/10/27/us-romania-chevron-idUSBRE99Q01V20131027

Infogazedesist.eu (2014). Re: Exploatarea gazelor de sist in Romania. Retrieved 18 Apr 2014 from http://forum.infogazedesist.eu/viewtopic.php? $\mathrm{f}=2 \& \mathrm{t}=1$

Karasz, P. (2012, Apr 22). Shale gas search divides Romania. New York Times. Retrieved 15 Dec 2013 from http://www.nytimes.com/2012/04/23/business/global/shale-gas-search-divides-romania.html?_r=1\&

Marinas, R. \& Patran, I. (2013, 23 Sep). Romania's Petrom eyes 1 billion euro investment next year, shale gas. Reuters. Retrieved 15 Dec 2013 from http://www.reuters.com/article/2013/09/23/us-eeurope-investment-petrom-idUSBRE98M0E020130923

Molnar, S. (2013a, 16 Mar). Chevron responds to Romanians fears of fracking. Natural Gas Europe. Retrieved 16 Apr 2014 from http://www.naturalgaseurope.com/romania-chevron-shale-gas-earthquakes-pollution

Molnar, S. (2013b, 7 Dec). Romanian anti-fracking protesters claim police used force at Chevron site. Natural Gas Europe. Retrieved 14 Dec 2013 from http://www.naturalgaseurope.com/chevron-silisteapungesti-romania-shale-gas-protests

Molnar, S. (2013c, 8 Dec). Romanian shale gas opponents invade Chevron site. Natural Gas Europe. Retrieved 14/12/2013 from http://www.naturalgaseurope.com/romania-violence-flares-at-chevronshale-site

Munteanu-Jipescu, C. (2013, Nov). Shale gas investments in Romania: legal challenges. Retrieved 14 Dec 2013 from http://www.romaniaog.com/RomaniaOG/media/Site_Images/ContentPhotos/Intercontinental/10-Claudiu-Munteanu-Jipescu.pdf

NGE, Natural Gas Europe (2013a, 2 Apr). Chevron, shale gas and Romania: Interview with Tom Holst. Retrieved 14 Dec 2013 from http://www.naturalgaseurope.com/chevron-shale-gas-romania-tomholst

NGE, Natural Gas Europe (2013b, 10 May). US major ready to start work in new Romanian location. Retrieved 14/12/2013 from http://www.naturalgaseurope.com/chevron-starts-work-in-romania

NGE, Natural Gas Europe (2013c, 12 Jun). EIA reports boost's Romania's shale gas potential. Retrieved 13 Dec 2013 from http://www.naturalgaseurope.com/romania-shale-gas-eia-report

Novinite.com (2013a, 8 May). Romania gives green light to shale gas fracking near Bulgarian border. Retrieved 15 Dec 2013 from http://www.novinite.com/view_news.php?id=150172

Novinite.com (2013b, 11 May). Bulgarians rise against Romania shale gas 'fracking' permit. Retrieved 15 Dec 2013 from http://www.novinite.com/view_news.php?id=150254

Novinite.com (2014, 9 Apr). Chevron to start exploration for shale gas in Romania. Retrieved 14 Apr 2014 from http://www.novinite.com/articles/159686/Chevron+Starts+Exploration+for+Shale+Gas+in+Romania

Otto, F. (2014). Romania protest movement. Retrieved 16 Apr 2014 from http://www.mpe-magazine.com/reports/romania-protest-movement

Pantazi, C. (2013, 5 Nov). Interviu video. [Interview with Tom Holst, country manager Chevron]. HotNews.ro. Retrieved 18 Apr 2014 from http://economie.hotnews.ro/stiri-energie-15958919-exclusiv-tomholst-country-manager-chevron-operatiunile-pungesti-vor-reluatecand-vom-decide-exista-conditii-siguranta-fracturarea-hidraulica- putea-utilizata-ultima-faza-lucrarilor-explorare-dar-are-n.htm Transcript in English: RoPepCa (2013). Tom Holst, country manager Chevron: Operations at Pungesti will be resumed "when we decide that the safety conditions are in place". Retrieved 18 Apr 2014 from http://www.ropepca.ro/en/media/membrii-in-media/tom-holst-countrymanager-chevron-operatiunile-de-la-pungesti-vor-fi-reluate-cand-vomdecide-ca-exista-conditii-de-siguranta/

Patran, I. (2013, 4 Apr). Thousands protest Chevron's shale gas plans in Romania. Reuters. Retrieved 15 Dec 2013 from http://www.reuters.com/article/2013/04/04/us-romania-shale-chevronidUSBRE9330S320130404

Petrescu, G. (2014, 22 Jan). Tension continues as Gagesti villagers oppose Chevron Romania's information campaign. Natural Gas Europe. Retrieved 18 Apr 2014 from http://www.naturalgaseurope.com/chevron-shale-information-campaign-gagesti-romania

Pirvoiu, C. (2012, 18 Jun). Romgaz a descoperit gaze de sist in urma cu 17 ani si ar putea sa treaca la faza de exploatare dupa anumite evaluari [Romgaz has discovered shale gas 17 years ago and could move to the exploitation phase after certain evaluations.] HotNews.ro. Retrieved 15 Apr 2014 from http://economie.hotnews.ro/stiri-energie-12553034romgaz-efectueaza-lucrari-explorare-gazelor-sist-circa-17-ani.htm

Presadă, F. (2012). Case study on the Romanian protests, 2012. The Resource Center for Public Participation, CeRe. Retrieved 14 Apr 2014 from http://www.ce-re.ro/upload/Romanian_Bucharest_Protests_2012.pdf

PwC \& Eurasia Group (2006). Integrating political risk into enterprise risk management. Retrieved 15 Apr 2014 from http://www.pwc.com/gx/en/political-risk-consulting-services/pdf/praermfinal.pdf

Revolution News (2013, 16 Oct). Romania: protests against Chevron shale gas well, camp and blockade construction site. Retrieved 15/12/2013 from http://revolution-news.com/romania-protests-againstchevron-shale-gas-well-camp-and-blockade-construction-site/

România libera (2013, 18 Oct). Romania: Pungești-Chevron case. Behind the scenes of a huge scandal. Retrieved 14 Dec 2013 from http://www.presseurop.eu/en/content/news-brief/4248191-punge-tichevron-case-behind-scenes-huge-scandal

SGE, Shale Gas Europe (2013a). Romania. Retrieved 15 Dec 2013 from http://www.shalegas-europe.eu/en/index.php/resources/shale-opportunities-in-europe/romania

SGE, Shale Gas Europe (2013b). Study confirms Romania has good shale gas potential. Retrieved 13 Dec 2013 from http://www.shalegaseurope.eu/en/index.php/news-room/blog/entry/study-confirms-romania-has-good-shale-gas-potential

Stoica, G. L. (2013, Jan). Civil Society in Romania and Central and Eastern Europe. South-East European Journal of Political Science. Retrieved 16 Apr 2014 from http://www.seejps.ro/volume-i-number-i-democracy-and-civil-society/10-civil-society-in-romania-and-centraland-eastern-europe.html

Stroe, D. (2014, 21 Feb). Romanian Orthodox Church denies financial deal with Chevron. Independen Balkan News Agency. Retrieved 16 Apr 2014 from http://www.balkaneu.com/romanian-orthodox-churchdenies-financial-deal-chevron/

Stroe, D. (2013, 1 Apr). In U-turn decision, Romania's PM Ponta says he favors shale gas exploration. Independent Balkan News Agency. Retrieved 14 Apr 2014 from http://www.balkaneu.com/u-turn-decisionromanias-pm-ponta-favors-shale-gas-exploration/

U.S. Energy Information Administration (2012). What is shale gas and why is it important? Retrieved 13 Dec 2013 from http://www.eia.gov/energy_in_brief/article/about_shale_gas.cfm

U.S. Energy Information Administration (2013). Romania. Retrieved 13 Dec 2013 from http://www.eia.gov/countries/countrydata.cfm? fips $=\mathrm{RO}$

Vişan, G. (2013, Jul). Public perception of shale gas in Romania. Policy Brief 3, Romania Energy Center. Retrieved 14 Apr 2014 from http://www.roec.ro/wp-content/uploads/2013/09/Visan_SG-PublicPerception-July-2013_EN.pdf

Wells, P. (2013, Jun). Technically recoverable shale oil and shale gas resources. U.S. Energy Information Administration. Retrieved 13 Dec 2013 from http://www.eia.gov/analysis/studies/worldshalegas/pdf/overview.pdf

Wickens, J. \& O'Brien, P. (2014, 18 Feb). Peasants' revolt. Romania at war with itself over fracking. Channel 4 News. Retrieved 18 Apr 2014 from http://www.channel4.com/news/fracking-romania-protestspungesti-chevron-victor-ponta 


\section{References Bulgaria}

24chasa (2013, 5 Jun). Орешарски: МВР показа сериозни дефекти, протести още на втория ден е рекорд [Oresharsky: Ministry of Interior showed serious defects, protests on the second day record]. 24 часa. Retrieved 19 Apr 2014 from http://www.24chasa.bg/Article.asp?ArticleId=2033364

3e (2011a, 3 Aug). BSP presidential candidate insists on referendum on shale gas. Energy Ecology Economy. Retrieved 14 Apr 2014 from http://3e-news.net/en/energy/bsp-presidential-candidate-insists-on-referendum-on-shale-gas_10499

3e (2011b, 22 Nov). Energy Minister: No referendum on shale gas is needed. A hysteria is being whipped up, Traicho Traikov said. Energy Ecology Economy. Retrieved 19 Apr 2014 from http://3enews.net/en/energy/energy-minister-no-referendum-on-shale-gas-isneeded_11710

Assenova, M. (2012, 24 Jan). Bulgarian government withdraws Chevron's shale gas permit. Eurasia Daily Monitor 9(16). Retrieved 15 Apr 2014 from http://www.jamestown.org/programs/edm/single/?tx_ttnews[tt_news]=38921\&cHash=e87f2f5212f2132dbc5e1648d 1038629\#.U05KTVchvIU

Assenova, M. (2013, 2 Jul). Bulgaria and Romania: Pursuing energy security in a changing environment. Center for European Policy Analysis. Retrieved 14 Apr 2014 from http://www.cepa.org/content/bulgaria-and-romania-pursuing-energy-security-changing-environment

Borisova, T. (2011, 2 Aug). Shale drilling: Bulgarians see benefits, risks. Southeast European Times. Retrieved 14 Apr 2014 from http://www.setimes.com/cocoon/setimes/xhtml/en_GB/features/setimes/features/2011/08/02/feature-02

Buzar, S. (2013, 29 Aug). Untangling the puzzle of energy policy in Bulgaria. Energy Vulnerability and Urban Transitions. Retrieved from http://urban-energy.org/2013/08/29/guest-contribution-untangling-thepuzzle-of-energy-policy-in-bulgaria/

Daborowski, T. \& Groszkowski, J.(09/2012). Shale gas in Bulgaria, the Czech Republic and Romania. Political conditions - legal issues - perspectives. Ośrodek Studiów Wschodnich. Retrieved 13/12/2013 from http://www.osw.waw.pl/sites/default/files/shale_gas_in_bulgaria_the_czech_republic_and_romania_net_0.pdf

Daborowski, T. (2012, 25 Jan). Bulgaria is no longer interested in shale gas. OSW Ośrodek Studiów Wschodnich - Centre for Eastern Studies. Retrieved 21 Feb 2013, from http://www.osw.waw.pl/en/publikacje/ceweekly/2012-01-25/bulgaria-no-longer-interested-shale-gas

Dimitrova, S. (2012, 30 Jan). Bulgaria may need to revise new shale gas law. Southeast European Times. Retrieved from http://www.setimes.com/cocoon/setimes/xhtml/en_GB/features/setimes/features/2012/01/30/feature-01

Economist (2014, 22 Jan). Romania and Bulgaria: depressing reading Retrieved 15 Apr 2014 from http://www.economist.com/blogs/easternapproaches/2014/01/romania-and-bulgaria

Euractiv (2012a, 16 Jan). Bulgarian protestors demand ban on shale gas | EurActiv. Retrieved 14 Feb 2013, from http://www.euractiv.com/climate-environment/bulgarians-protest-shale-gas-ban-news-510163

Euractiv (2012b, 7 Feb). US tells Bulgaria shale gas is safe. Retrieved 16 Apr 2014 from http://www.euractiv.com/energy/us-tells-bulgariashale-gas-safe-news-510616

European Commission (2014a). Agriculture. Member states factsheets: Bulgaria. Retrieved 16 Apr 2014 from http://ec.europa.eu/agriculture/statistics/factsheets/pdf/bg_en.pdf

Eurostat (2013, 15 Nov). GDP per capita in PPS. Retrieved 15 Apr 2014 from http://epp.eurostat.ec.europa.eu/tgm/table.do?tab=table \&plugin $=1 \&$ language $=$ en $\&$ pcode $=$ tec 00114

Georgiev, A. (2010, 5 Mar). Bulgaria - gas consumer or future gas hub? European Energy Review. Retrieved from http://www.europeanenergyreview.eu/site/pagina.php?id=1764

Groszkowski, J. \& Daborowski, T. (2012, 10 Dec). The big fracking chill in Eastern Europe. European Energy Review. Retrieved 15 Feb 2013 from http://www.europeanenergyreview.eu/site/pagina.php?id=4000\&zoek=shale\%20gas\%20europe

Ivanova, М. (2013, 5 Jun). Мораториумът върху добива на шистов газ няма да се отменя[Moratorium on shale gas will not be repealed]. Investor.bg. Retrieved 19 Apr 2014 from http://www.investor.bg/ikonomika-i-politika/332/a/moratoriumyt-vyrhu-dobiva-nashistov-gaz-niama-da-se-otmenia, 152242/

Kassabov, O. (2012, 1 Feb). Will Hillary Clinton lobby for Chevron, shale gas in Bulgaria? Novinite.com. Retrieved 15 Apr 2014 from
http://www.novinite.com/articles/136275/Will+Hillary+Clinton+Lobby+for+Chevron,+Shale+Gas+in+Bulgaria\% $3 \mathrm{~F}$

Kassabov, O. (2010a, 22 Nov). Direct Petroleum Manager Kolyo Tonev: Bulgaria stands to huge investments from shale gas discovery. Novitine.com. Retrieved from

http://www.novinite.com/view_news.php?id=122433

Kassabov, O. (2010b, 25 Nov). Shale gas in Bulgaria. Is a US-led breakthrough imminent? Novinite.com. Retrieved from http://www.novinite.com/view_news.php?id=122561

Konstantinova, E., \& Carroll, J. (2012, January 19). Bulgaria Bans Gas Fracking, Thwarting Chevron Drilling Plan. BusinessWeek: undefined. Retrieved from http://www.businessweek.com/news/2012-0119/bulgaria-bans-gas-fracking-thwarting-chevron-drilling-plan.html

NGE, Natural Gas Europe (2010, 7 Oct). Bulgaria grants permit for shale gas prospecting. Natural Gas Europe. Retrieved from http://www.naturalgaseurope.com/bulgaria-grants-permit-for-shale-gas-prospecting

NGE, Natural Gas Europe (2011a, 19 July). Bulgaria addresses environmental concerns over shale gas. Retrieved from http://www.naturalgaseurope.com/bulgaria-concernsshale-gas-exploration

NGE, Natural Gas Europe (2011b, 8 Oct). Bulgaria pledges risk assessment for shale gas. Retrieved from http://www.naturalgaseurope.com/bulgaria-pledges-risk-assessment-for-shale-gas-2894

NGE, Natural Gas Europe (2012, May 2). Analysis: Bulgaria's shale gas and the wider geo-economic game. Retrieved February 14, 2013, from http://www.naturalgaseurope.com/analysis-bulgarias-shale-gas-andthe-wider-geo-economic-game-4736

NGE, Natural Gas Europe (2013, 12 Apr). Shale gas in Bulgaria: an interview with Tomasz Daborowski. Retrieved 15 Apr 2014 from http://www.naturalgaseurope.com/bulgaria-shale-gas-development

Novinite.com (2010a, $13 \mathrm{Jul})$. US ambassador presents major gas alternative for Bulgaria. Retrieved from http://www.novinite.com/view_news.php?id=118076

Novinite.com (2010b, 9 Nov). Bulgarian energy minister reprimands US ambassador on shale gas. Retrieved 18 Apr 2014 from http://www.novinite.com/view_news.php?id=121980

Novinite.com (2011a, 21 Jan). BNK Petroleum eyes Bulgarian shale gas resources. Retrieved from http://www.novinite.com/view_news.php?id=124390

Novinite.com (2011b, 15 June). Bulgarian govt grants Chevron massive shale gas exploration concession. Novinite.com. Retrieved from http://www.novinite.com/view_news.php?id=129323

Novinite.com $(2011 \mathrm{c}, 19 \mathrm{Jul})$. Bulgaria to finalize shale gas contract with Chevron in days. Retrieved 21 Jul 2013, from http://www.novinite.com/view_news.php?id=130395

Novinite.com. (2011d, 10 Aug). Angry Bulgarians protest shale gas exploration. Retrieved February 15, 2013, from http://www.novinite.com/view_news.php?id=132785

Novinite.com (2012a, 18 Jan). Bulgaria adopts total ban on hydrofracking for shale gas in u-turn decision. Retrieved 15 Apr 2014 from http://www.novinite.com/view_news.php?id=135842

Novinite.com (2012b, 18 Jan). US Ambassador to Bulgaria: do you really want to chase away Chevron? Retrieved 15 Apr 2014 from http://www.novinite.com/view_news.php?id=135819

Novinite.com (2012c, 19 Jan). Bulgarian govt will reverse shale gas ban within months - expert. Retrieved 15 Feb 2014 from http://www.novinite.com/view_news.php?id=135875

Novinite.com (2012d, 23 Jan). Bulgarian econmin: huge money at stake over shale gas. Retrieved 15 Apr 2014 from http://www.novinite.com/view_news.php?id=135970

Novinite.com (2012e, 14 Feb). Bulgarian experts to set up Movement for Energy Independence. Retrieved 15 Apr 2014 from http://www.novinite.com/articles/136653/Bulgarian+Experts+to+Set+Up+Movement+for+Energy+Independence

Novinite.com (2013, 3 Jun). Bulgaria's environment minister decries shale gas moratorium. Retrieved 21 Jul 2013, from http://www.novinite.com/view_news.php?id=150928

Sega (2013, 3 Jun). Екоминистърът се усъмни в ефективността на мораториума върху шистовия газ [Environment minister questions effectiveness of shale gas moratorium]. Retrieved 15 Apr 2014 from http://www.segabg.com/article.php?id=651333

Shaffer, B. (2014, 11 Mar). Pipeline problems. Ukraine isn't Europe's biggest energy risk. Foreign Affairs. Retrieved 16 Apr 2014 from http://www.foreignaffairs.com/articles/141023/brenda-shaffer/pipeline-problems 
Sofia Echo (2012, 7 Mar). Bulgaria rejects Chevron bid, cancels four oil exploration tenders. Retrieved 19 Apr 2014 from http://sofiaecho.com/2012/03/07/1782412_bulgaria-rejects-chevron-bid-cancels-four-oil-exploration-tenders

Sotirov, I. (2012, 2 Feb). Иван Сотиров: Руско лоби срещу шистовия газ. [Ivan Sotirov: Russian lobby against shale gas]. Trud. Retrieved 15 Apr 2014 from http://m.trud.bg/Article.aspx?Id=1213382

Stefanov, R. \& Tsanov, M. (2012). Bulgarian energy policy. Aspen Review Central Europe (Aspen Institute, Prague), 83-87. Retrieved from http://www.aspeninstitute.cz/images_upload/files/Aspen\%20Review/Bulgarian_Energy_Policy.pdf

UPI (2012, 6 Feb). U.S. energy czar en route to Bulgaria. Retrieved 16 Apr 2014 from http://www.upi.com/Business_News/Energy-Resources/2012/02/06/US-energy-czar-en-route-to-Bulgaria/UPI47431328533231/

U.S. Energy Information Administration (2013, Jun). Technically recoverable shale oil and shale gas resources: an assessment of 137 shale formations in 41 countries outside the United States. Retrieved 15 Apr 2014 from http://www.eia.gov/analysis/studies/worldshalegas/pdf/fullreport.pdf?zscb=30495135

Sahraoui, Y. (2012, 10 Sep). The geopolitics of shale gas in Europe: interview with Dr. Aviezer Tucker. Natural Gas Europe. Retrieved 16 Apr 2014 from http://www.naturalgaseurope.com/geopolitics-of-shalegas-in-europe-aviezer-tucker

Stoyanov, V. (2013, 18 Oct). How to turn Bulgaria into Eastern Europe's energy hub and gateway. Energy Post. Retrieved 19 Apr 2014 from http://www.energypost.eu/how-to-turn-bulgaria-into-eastern-europesenergy-hub-and-gateway/

Tucker, A. (2012a, $13 \mathrm{Jul})$. New cold war over shale gas. Russia inflames environmental fears to dominate energy market. Washington Times. Retrieved 16 Apr 2014 from http://www.washingtontimes.com/news/2012/jul/13/new-cold-war-over-shale-gas-russia-inflames-enviro/

Tucker, A. (2012b, 19 Dec). The new power map. World politics after the boom in unconventional energy. Foreign Affairs. Retrieved 16 Apr 2014 from http://www.foreignaffairs.com/articles/138597/aviezertucker/the-new-power-map?page=show

Vassilev, B. (2012, 2 Feb). Hit the gas. Transitions Online. Retrieved from http://www.tol.org/client/article/22976-hit-the-gas.html?print

Vikhrov, V. (2013, 3 Mar). Energy geopolitics: the economic and socia crisis in Bulgaria. Centre for Research on Globalization. Retrieved 14 Apr 2014 from http://www.globalresearch.ca/energy-geopoltics-theeconomic-and-social-crisis-in-bulgaria/5324997

Warlick, J. (2012, 27 Jan). Ambassador Warlick op-ed on shale gas. Embassy of the United States, Sofia. Retrieved 15 Apr 2014 from http://bulgaria.usembassy.gov/amb speech01272012.html

Wood, J. (2013). The global anti-fracking movement. What it wants, how it operates and what's next. Control Risks. Retrieved 16 Apr 2014 from http://www.controlrisks.com/ /media/Public\%20Site/Files/Oversized\%20Assets/shale_gas_whitepaper.pdf 